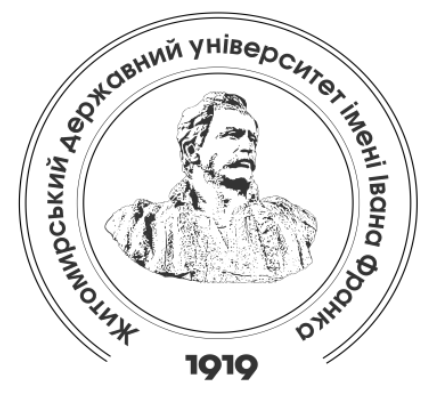

Zhytomyr Ivan Franko State University Journal. Pedagogical Sciences. Vol. 3(98)

Вісник Житомирського державного університету імені Івана Франка. Педагогічні науки. Вип. 3(98)

ISSN (Print): 2663-6387

ISSN (Online): 2664-0155

UDC 378.011.3:81'243:376

DOI 10.35433/pedagogy.3(98).2019.43-49

\title{
THE CONCEPTUAL IDEA OF WOULD-BE ENGLISH TEACHERS' PREPARATION TO PRACTICE-ORIENTED INSTRUCTION OF LEARNERS WITH DISABILITY
}

\section{N. S. Scherba*, O. S. Zablotska ${ }^{* *}$}

The introduction of inclusive instruction of children with special educational needs is one of the most topical tendencies of Ukrainian secondary education reform. In the last decades a number of measures have been taken in the course of its implementation, and namely: the educational legislation has been upgraded, a number of pilot projects have been launched, the position of a teacher aide has been introduced, a number of school premises have been (re)constructed in the frameworks of reasonable adjustment and universal design etc. In the same time, the question of would-be teachers' (and namely, of foreign language) preparation to the practice-oriented instruction of learners with disability has not been sufficiently researched. The theoretical and methodological analyses previously done allowed us to formulate its conceptual idea described in the article. According to it, the structural components of would-be teachers' preparation to challenged learners' instruction should include: motivation, content, organization and evaluation ones. The motivation component presupposes the interiorization of values that reflect the UN's paradigm of new humanism. These primarily comprise so-called integration models of disability. The content component includes, on the one hand, raising would-be teachers' awareness of the theoretical issues connected to the peculiarities of learners with disability of 5 categories and of teaching them foreign languages; and on the other one - developing students' ability to substantiate the choice of measures to be taken as a solution in challenging classroom situations. The organization component includes activities aimed at the practical study of adjustment and correction measures in the context of teaching learners with disability. And finally, the evaluation component presupposes the application of such means and methods of evaluating the results of the pedagogical preparation as: traditional and online tests, as well as the case and project methods of learning.

\footnotetext{
${ }^{*}$ Candidate of Pedagogical Sciences, (PhD in Pedagogy), Docent

(Zhytomyr Ivan Franko State University)

scherbanatasha@gmail.com

ORCID: 0000-0002-5467-4292

** Doctor of Pedagogical Sciences, Professor (Communal Higher Educational Institution

"Zhytomyr Medical Institute")

olgazab155@gmail.com

ORCID: 0000-0002-0850-5754
} 
Key words: would-be foreign language teachers' preparation, learners with disability, the structure of the preparation, the axiological component, the cognitive component, the instrumental component, the reflective component, practice-oriented instruction.

\title{
КОНЦЕПТУАЦЬНА ІДЕЯ ПІДГОТОВКИ МАЙБУТНІХ УЧИТЕАІВ ІНОЗЕМНОЇ МОВИ ДО ПРАКТИКООРІЕНТОВАНОГО НАВЧАННЯ УЧНІВ З ІНВАМІДНІСТЮ
}

\author{
Н. С. Щерба, О. С. Забцоцька
}

\begin{abstract}
Запровадження інклюзивного навчання дітей з особливими освітніми потребами $\epsilon$ съогодні однією з найактуальніших тендениій реформування вітчизняної середньої освіти. За останні десятиріччя в ході ї̈ реалізаиї в Україні було запроваджено низку заходів, зокрема: оновлено освітньо-нормативну базу, започатковано декілька пілотних експериментів, введено посаду асистента виителя, використано особливості розумного пристосування та універсального дизайну в проектуванні шкільних примішень тошо. Проте питання підготовки майбутніх учителів (і зокрема іноземної мови) до навчання учнів з інвалідністю залишається відкритим. Проведений нами аналіз теоретикометодологічних основ такої підготовки дозволив сформулювати ї̈ кониептуальну ідею, описану в статті. Відповідно до неї структурними компонентами підготовки майбутнъого вчителя до навчання учнів з інвалідністю мають стати: мотиваиійний, змістовий, організаиійний та контрольно-оиінний. Мотиваиійний компонент передбачає привласнення студентами иінностей, шо реалізують кониепиію нового гуманізму ООН. До таких, у периу чергу, належать інтеграиійні моделі інвалідності. Змістовий компонент зумовлює, з одного боку, засвоєння майбутніми виителями теоретичного матеріалу, ио стосуеться особливостей учнів з інвалідністю 5 категорій та їх навчання іноземної мови, а з іншого - розвиток їх здатності обтрунтувати причини для вибору того чи іншого способу вирішення проблемної педагогічної ситуаиї. Організаиійний компонент включає в себе завдання, спрямовані на практичне засвоєння способів адаптаиї та корекиії в умовах навчання учнів з інвалідністю. Нарешті, контрольно-оиінний компонент передбачає запровадження таких засобів і методів контролю та оиінювання результатів педагогічної підготовки як: традииійні та онлайн-тести, а також кейсовий і проектний методи.
\end{abstract}

Key words: підготовка вчителя іноземної мови, учні з інвалідністю, структура підготовки, аксіологічний компонент, когнітивний компонент, інструментальний компонент, рефлексивний компонент, практикоорієнтоване навчання.

Introduction of the issue. The globalization tendencies that have been affecting Ukrainian secondary education for several decades have touched upon the subject of including special educational needs (SEN) learners into mainstream schools. It caused a number of challenges that are being gradually met by the Ministry of Education and Science of Ukraine and other governmental and nongovernmental institutions. A number of measures have been taken and among them are: changes in the legislation, educational subsidy and teacher aide 44 position introduction, regional inclusion projects piloting, school premises reconstruction from the perspective of reasonable adjustment and others. In the same time the questions of preparing would-be teachers to SEN learners' instruction have not been sufficiently highlighted, which explains the topicality of the research presented in the article.

Current state of the issue. The problem of would-be foreign language teachers' preparation to SEN learners' instruction is connected to a number of relevant questions that have been 
analyzed by Ukrainian and foreign scientists:

- the forms of teaching learners with disability in mainstream schools (mainstreaming, integration and inclusion) have been researched by: V. I. Bondar,

L. I. Danylchenko,

M. Y. Chaikovskiy,

T. Illiashenko, M. F. Giangreco,

L. V. Kalmykova,

I. B. Kuzava,

N. N. Malofieiev,

A. Saez,

L. M. Shypitsina,

V. M. Syniov,

I. O. Kalinichenko,

A. A. Kolupayeva,

I. A. Malyshevska, C. J. W. Meijer,

N. D. Shmatko, K. Snow,

K. Perles, H. M. Warnock, A. M. Zotova;

- the didactic bases of teaching learners with disability in mainstream educational institutions have been highlighted by: B. C. Gartin, M. Imbeau, L. V. Kalmykova, A. A. Kolupaieva, N. L. Murdick, Y. M. Nayda, V. V. Nechyporenko, D. E. Perner, T.V Sak, P. I. Sikorskiy, Y. S. Siliavina, O. V. Sokolnikova, O. M. Taranchenko, S. M. Tomchuk, C. A. Tomlinson;

- the essence of the practical orientation of teaching in the system of secondary education was analyzed by: M. K. Alfierieva, L. V. Guliayeva, Y. A. Bielovolova, A. G. Mordkovych, P. V. Semenov, L. V. Pavlova;

- the concept of practice-oriented vocational education was analyzed by: T. N. Bondarenko, A. P. Latkin, V. Y. Vanieva, Y. Vetov, N. Klushina, S. M. Vishniakova, O. D. Demchenko, O. M. Kotikova, P. I. Obraztsov, A. I. Uman, L. V. Potapienko,

T. I. Morozova, M. Y. Vilienskiy, K. S. Pitsul, in pre-service teacher training - by: S. V. Bobrakov, D. Varneke, E.-M. Post, S. Pitsch, L. Ayzikova, Y. B. Novikova and others.

The outline of unresolved issues brought up in the article. But the concept of practice-oriented SEN learners' instruction and the peculiarities of preparing would-be foreign language teachers to it were not highlighted in the scientific sources analyzed.

Aim of research. Taking into consideration the topicality of the issues mentioned above and the insufficient state of the relevant teacher training, the purpose of the article was to highlight the conceptual idea of preparing would-be teachers of foreign language to practice-oriented SEN learners' instruction in the mainstream setting.

Results and discussions. The essence of the concept of "practiceoriented SEN learners' instruction" was defined by means of the content analysis and its further specification in the pedagogical context chosen.

The content analysis was performed at four stages. The first stage was dedicated to the formulation of its topic ("practice-oriented instruction"), task ("to create its scientifically grounded definition") and hypothesis. The latter was formulated as an assumption that practice-oriented instruction is an educational process aimed at the preparation of persons to the solution of a sufficient minimum of issues in a definite field. After that the selection of definitions was compiled. It consisted of 61 definition of practice-oriented instruction by Ukrainian and foreign scholars.

The second stage was aimed at selecting categories and units of context, analysis and counting. The categories of analysis included openended questions to be answered after studying the selected definitions. The answers were analyzed and words, word-combinations and their synonyms repeated in the definitions were counted. These words and a wordcombinations were chosen as the analysis units. The number of repetitions in analysis units were named the units of counting. 
At the third stage a chart was built. It was used as a coding matrix both: for the elaboration of the categorial apparatus and for registering the analysis units. The chart consisted of 5 columns. The first one reflected the process of creating the definition of the term "process-oriented instruction". The second one contained the sequence numbers. The third one demonstrated words and word-combinations (analysis units) demonstrating the answers to the open-ended questions. The ones with the highest frequency of repetition were added to the definition of the term (in the first column). The fourth column included the number of repetitions of the units mentioned. Finally, the fifth column contained the same information in the percent form.

The fourth stage was dedicated to the counting of the results of the content analysis and the creation of the term definition.

Thus, the materials of the coding matrix reflected the process of compiling the term definition after answering each open-ended question.

The content analysis resulted in the following definition draft: practiceoriented instruction is a combination of instruction and practical activity used for the solution of important tasks and challenges which helps to obtain new knowledge and experience of its application by means of emotional and cognitive filling of learners' creative search and by ensuring their vocational guidance. Taking into consideration the peculiarities of teaching foreign language and of senior SEN learners' instruction, the draft definition was given more precision. Accordingly, practice-oriented instruction was defined as "a two-sided process of learners' communicative competence development that serves a prerequisite for their social integration that is realized by means of the solution of important tasks and challenges combining instructional and paraprofessional activities, as well as emotional and cognitive filling of creative search".

In its turn, the conceptual idea of would-be foreign language teachers' preparation to practice-oriented senior SEN learners' instruction characterized further is our view of the problem solution based on its methodological analysis.

First of all, the system of preparing would-be teachers of foreign language to the instruction of learners with disability is viewed as a component of their professional pre-service education. It is based upon teaching the courses that refer to Psychology, Pedagogy, Methodology, ICT studies etc. Thus, the relevant course should be implemented as a component of the Master's degree program.

The system of the preparatory course should include the following components: motivation, content, organization and evaluation ones. The motivation component is viewed as connected to the transformation of students' culturally relevant values shared by most Ukrainians [8] and contributing to the violation of human right for social inclusion concerning people with disability. The values mentioned are expressed in so-called models of disability [7] and namely in the isolation ones. Thus, the aim of introducing the motivational component of the preparation is to help students revise their isolation models if any, and to develop the integration ones. The key motivation basis for inclusive teaching learners with disability is the theory of new humanism, promoted as a new humanity paradigm by UN [3]. According to it, educational and subsequent social inclusion of everyone belong to the key values of the humanity. This statement is supposed to affect would-be teachers' motifs and beliefs in the professional activities. In the academic context, the mechanisms 
that underlie "the humanization" of would-be teachers' motivational field are suggested by the theory of the social constructivism according to which "the individual pictures of correct and incorrect world" are shared and specified in the process of communication [1] (and classroom communication as well). This leads us to the choice of the content that would promote students' interiorization of humanistic values and to the choice of interaction as the prevailing mode of learning. In the same time, according to Ringelman's theory, people in large groups tend to underestimate their own significance and contribute less effort into group activities as a result [9]. That is why the number of students involved into activity groups should be minimal (2-4 students).

The content component of the system of would-be foreign language teachers' preparation to SEN learners' instruction was named this way as it primarily deals with such activities as: raising students' awareness of forms and manifestations of different categories and severity of disability, possibilities and restrictions of SEN learners' performance and their special needs resulted from these; of inclusion, adjustment, modification, individualization, differentiation and other theoretical concepts of the course. In the same time, it is aimed at developing students' ability for reasonable decision making according to the peculiarities of the individual learner's case. In other words, students should be able to interpret processes and mechanisms underlying teaching pupils with disability and be able to substantiate pedagogical measures suggested for meeting challenges. As the key idea of teaching SEN learners is their preparation for effective future social integration, their instruction should be practice-oriented, that is, aimed at developing their readiness to meet topical routine and professional challenges that involve the usage of a foreign language. Likewise, the mentioned preparation of would-be foreign language teachers should be practically oriented. That is why among the philosophical and theoretical bases of both: of SEN learners' instruction and of would-be teachers' preparation, we single out the ideas of neopragmatism, activity theory, contextual approach and project technology $[2 ; 4 ; 5 ; 10]$. The main drawbacks of neopragmatism, which have to be eliminated, are: the lack of axiological impact that is made on a learner and a low theoretical level of the academic interaction content. But in the same time, it presupposes the selection of tasks and activities on the basis of their practical value. The activity theory views both the teacher and a learner as subjects of the instructional process. This means that the latter gives them opportunities to meet their individual educational, professional and other needs, classified in A. Maslow's hierarchy [6]. It leads to raising the independence of learners by means of exposing the practical value of tasks and activities and by teaching them strategies of problem-solving. According to the contextual approach, learning materials and procedures should be enriched by practically valuable routine and paraprofessional challenges included into curriculum topics and feasible for learners. A prerequisite for keeping the level of learners' and students' activeness high is the pedagogy of partnership that introduces a peculiar distribution of teacher's and learner's roles. Teacher is a planner, organizer, facilitator, consultant and controller of instructional and preparation processes. In their turn, SEN learners and students are active participants of learning and preparation.

The organization component of the preparation deals with developing students' ability to apply adjustment, 
modification,

correction, individualization and differentiation procedures in teaching foreign language different categories of learners with disability and learning challenges. These mainly include additional or specially adjusted activities that can help learners overcome difficulties in learning foreign languages. It also embraces the process of developing the ability to produce practice-oriented tasks and activities in the context of topics and situations assigned by the curriculum.

At last, the evaluation component includes the means and procedure of control and evaluation. The correspondent means can include systematic classroom tests, both traditional and online. The latter can be suggested online, e.g. in a virtual learning environment Edmodo, which supports 5 kinds of quizzes: true / false, matching, multiple choice, inserting and 1-word-answer. As for other methods and procedures, we can suggest case and project methods. While accomplishing these, would-be teachers can group-up and be given a description of a learner's restrictions (physical, emotional, social and intellectual) and learning challenges that are derived from the former. Students can be suggested individual tasks (e. g.: to give adjustment suggestions to make up for a learner's physical restrictions; to suggest the extent of content modification according to the learner's intellectual challenges etc.). As every student completes the individual task, they can communicate and produce a complex group solution for the challenge, presented in the case.

\section{Conclusions and research} perspectives. The professional preparation of would-be foreign language teachers to the inclusive instruction of learners with disability is a crucial question for Ukrainian secondary education, as it is a teacher who is responsible for the success or failure of pupils. The relevant pedagogical system should be built considering the ideas of: new humanism, neopragmatism, activity theory, Hofstede's theory of cultural dimensions, theories of social constructivism and of disability models, axiological and project approaches, Ringelman's effect and Maslow's hierarchy of needs, pedagogy of cooperation and Bloom's taxonomy. This way it will give a possibility to embrace all the key components of the preparation enumerated above.

\section{REFERENCES (TRANSLATED \& TRANSLITERATED)}

1. Borodina, D.L. (2014). Kontseptsia sotsialnogo konstruyuvannia realnosti P. Bergera i T. Lukmana yak interpretatsiyna schema doslidzhennia imidzhu mista [The concept of P. Berger's and T. Lukman's social reality construction as a scheme for a city image research]. Sotsiologiia. Hrani, 10 (1 14), 80-84 [In Ukrainian].

2. Vaniyeva, V.Y. (2015). Praktikoorientirovannyi podkhod $k$ podgotovke studientov - budushchikh logopiedov $k$ profiessionalnoi dieyatielnosti [The practice-oriented approach to the preparation of students - would-be speech therapists to the professional activity] [Electronnyi resurs]. Internetzhurnal "Naukoviedieniie". 7 (5). Retrieved from https://cyberleninka.ru/article/v/prak tiko-orientirovannyy-podhod-kpodgotovke-studentov-buduschihlogopedov-k-professionalnoydeyatelnosti [In Russian].

3. Gorbunova, L

Transkulturna osvitnia strategiia $v$ konteksti vyklykiv globalizatsii [Transcultural educational strategy in the context of globalization challenges]. Filosofiia osvity, 1 (14), 158-198 [In Ukrainian].

4. Dubaseniuk, O.A., Semeniuk, T.V. Antonova, O.Y. (2003). Profesiina pidgotovka maibutniogo 
vchytelia do pedagogichnoi diialnosti: monografiia [The professional preparation of a would-be teacher to the pedagogical activity: monography]. Zhytomyr: Vyd-vo ZhDU imeni Ivana Franka [In Ukrainian].

5. Karmin, A.S., Bernatskiy, G.G. (2007). Filosofiia: uchebnik dlia vuzov. 2-ye izd-e. [Philosophy: the $2^{\text {nd }}$ edition]. $\mathrm{SPb}$ : Pitier [In Russian].

6. Piramida potreb liudyny za Maslou: 7 osnovnykh rivniv [Maslow's pyramid of human needs: 7 key levels]. Elektronnyi zhurnal "Biznes svit". Retrieved from https://busines.in.ua/ piramidapotreb-lyudyny-za-maslou-7-osnovnyhrivniv/ [In Ukrainian].

7. Sokur, N., Shulgina, T. (2016). Souriemiennyie probliemy sotsialnoi politiki $v$ sfierie zashchity lits $s$ invalidnostyu $v$ Ukrainie [The modern problems of the social defence of persons with disability in Ukraine] Aktualni problem derzhavnogo upravlinnia, 1(65), 88-91 [In Russian].
8. Sotsialna inkliuziia $v$ Ukraini: nyzkyi riven pryiniattia naibilsh vrazlyvykh ditei [Social inclusion in Ukraine: low level of accepting the most vulnerable children]. Retrieved from https://tsn.ua/ukrayina/socialnainklyuziya-v-ukrayini-nizkiy-rivenpriynyattya-naybilsh-vrazlivih-ditey542073.html [In Ukrainian].

9. Latané, B., Williams, K., Harkins, S. (1979). Many hands make light the work: The causes and consequences of social loafing. Journal of Personality and Social Psychology. 37(6), 822-832 [In English].

10. Rogers, C.R. (1962). Toward becoming a fully functioning person. In A. W. Combs (ed.) \& Association for Supervision and Curriculum Development, Perceiving, behaving, becoming: A new focus for education Washington, DC: National Education Association, 21-33 [In English].

Received: August 19, 2019 Accepted: September 12, 2019 